\title{
THE IMPACT OF EARLY MARRIAGE ON PREGNANCY: YOUNG WOMEN'S KNOWLEDGE
}

\author{
Ifna Rosydah ${ }^{1}$, Taty Hernawaty ${ }^{2}$, Imas Rafiyah ${ }^{3}$ \\ Faculty of Nursing, Universitas Padjadjaran \\ Corresponding email: taty.hernawaty@unpad.ac.id
}

\begin{abstract}
Women who were married at a young age and got pregnant had a risk of experiencing complications in pregnancy, and contribute $99 \%$ of maternal and infant deaths. Knowledge on the impact of early marriage on pregnancy is needed to prevent an increase of risked pregnancy cases. However, information about the impact of early marriage on pregnancy especially in young women population is limited. This study aimed to determine young women's knowledge about the impact of early marriage on pregnancy in the Margajaya Public Health Center. The design of this study was quantitative descriptive. The population of this research was 81 women who had early marriage, the sample was selected using the total sampling method. Data were collected using a questionnaire with the Gutmann scale and analyzed using frequency distribution. The results of the analysis were categorized as good, sufficient and poor. The results of the study found that most women had good knowledge about the impact of early marriage on pregnancy which was 46 respondents $(57 \%)$, moderate was 24 respondents $(29.6 \%)$, and poor were 11 respondents $(13.5 \%)$. The majority of women had limited understanding about preeclampsia. It was concluded that women's knowledge of early marriage and pregnancy was good, although there was a small number that is moderate and poor. Knowledge of women is less related to preeclampsia and eclampsia, there is a need for health education about preeclampsia and eclampsia for women who had an early marriage.
\end{abstract}

Keywords: Early Marriage, Impact, Pregnancy, Knowledge.

\section{INTRODUCTION}

Early marriage is marriage under the age of 18 (Ali, Ibrahim, Abdelgbar \& Elgessim, 2014). The Indonesian constitution Number 1 the Year 1974 article 7 section 1 concerning marriage regulated that marriage is permitted if the man is 19 years old and the woman is 16 years old with parental permission. Around the world, more than 650 million women got married at an early age every day. About one in six women (age 15 to 19 years) are married (UNICEF, 2018). Based on data from the Central Statistics Agency in 2016, the percentage of married women at the age of 16 was $15.69 \%$. West Java was the province with the highest rate of early marriage, especially in rural areas with $29.92 \%$. (BPS, 2016).

Early marriage causes some physical and psychological effects. Women who married early tend to be poor in socializing, quitting education, experiencing divorce, and poor households. In addition, reproductive effects are also experienced by early married women such as pain and trauma during sexual intercourse, lack of knowledge on the 
Ifna Rosydah : The Impact of Early Marriage on Pregnancy: Young Women's Knowledge

control of the pregnancy distance, and complications that occur during pregnancy or childbirth (Reuben, 2014).

Early married women married who got pregnant are at risk of experiencing complications in pregnancy. The World Health Organization (2018) stated that in developing countries, 21 million women aged 15 to 18 experienced pregnancy and contribute $99 \%$ of deaths to mothers and infants. According to Ganchimeg's study, et al. (2013) pregnant women younger than 18 years have a higher risk of developing preeclampsia and eclampsia, postpartum endometritis, and systemic infections. Ezegwui's research, Ikeako, and Ogbuefi (2011) stated that young pregnancy would cause anemia, pelvic disproportion which is an indication of cesarean section, and perinatal death. In addition, the World Health Organization (2018) also stated that giving birth at a young age could increase the risk of harming newborns. Mothers who give birth to babies under the age of 18 years are at higher risk of having children with low birth weight (LBW), premature birth, and complications after birth (WHO, 2018).

Based on the results of a preliminary study from the Margajaya Public Health Center the incidence of LBW (low birth weight babies) in 2016 was 16 babies (14.68\%) and increased to 18 babies (15.79\%) in 2017. Moreover, the maternal mortality rate (MMR) in 2017 was 1 mother died from severe preeclampsia with a background of marriage at the age of 16 years. Whereas, the mortality rate in 2016 was 10 babies dead caused by Pneumonia, LBW, and Asphyxia.

Identification based on knowledge for the first step in overcoming the impact of early marriage on health aspects needs to be carried out. WHO guidelines for early pregnancy and poor reproductive outcomes among adolescents in developing countries recommends actions and researches to prevent early pregnancy by increasing knowledge and understanding of the importance of preventing or delaying pregnancy before the age of 18 years. Knowledge of cognitive is an important domain for the formation of one's actions (Notoatmodjo, 2007). Qualitative research conducted by Nasrullah, et al. (2014) stated that the majority of respondents who got married early in Pakistan had low education or uneducated, had a low economy, worked as domestic servants, and the majority did not know the negative effects of early marriage on health.

The results of a preliminary study conducted at the Tanjungsari Religious Affairs Office said that bride and groom should receive guidance from the Public Health Center, Religious Affairs Office and Special Bride and Groom Advisory Board. The public health center has the responsibility to explain about delaying pregnancy and providing information about the impact of early marriage on health, but this responsibility is not 
Ifna Rosydah : The Impact of Early Marriage on Pregnancy: Young Women's Knowledge

performed, and guidance from religious affair office is also obstructed due to various reasons. The cadre of the Margajaya Public Health Center informed that early married women were not educated. However, information about the impact of early marriage on pregnancy especially in young women population is limited. This study aimed to examine women's knowledge of the impact of early marriage on pregnancy in the work area of the Margajaya Public Health Center.

\section{METHODS}

The type of this research was descriptive quantitative. The population in this study were married women aged $\leq 18$ in 2017 in the Margajaya Community Health Center area which include Margajaya, Kutamandiri, Raharja, Gunungmanik, and Cinanjung Villages. 81 young women were participated in this study.

Data collection used a closed questionnaire contained 24 items with the alternative answer of "True" and "False". Data analysis was performed by the descriptive method by looking at the percentage of data collected then presented in the form of a frequency distribution table. The measurement results of knowledge were categorized into good, sufficient, and poor knowledge. Good knowledge was categorized if the respondent answered $\geq 75 \%$ correctly, sufficient knowledge if the respondent answered $56 \%-75 \%$ correctly and poor if the answer were $<55 \%$ correct. This research received permission from the Research Ethics Commission of Padjadjaran University with ethical numbers 737 / IN6.KEP / EC / 2018.

\section{RESULT}

The characteristics of respondents and women's knowledge about the impact of early marriage on pregnancy are as follows:

Table 1 Characteristic of Respondents $(n=81)$

\begin{tabular}{lcc}
\hline \multicolumn{1}{c}{ Characteristic } & Frequency (f) & Percentage (\%) \\
\hline Age during Marriage & 8 & \\
10-14 & 73 & 9,9 \\
years & & 90,1 \\
15-18years & & \\
Last Education & 20 & 24,7 \\
Elementary School & 51 & 63 \\
Junior High School & 10 & 12,3 \\
Senior High School & & \\
\hline
\end{tabular}




\section{Occupation}

Yes

$9 \quad 11,1$

No

\section{Religion}

Moslem

\section{Number of Children}

0

$1-2$

$>2$

\section{Income}

$<$ Rp2.678.028,99

\section{Information about pregnancy}

Yes

No

\section{Information Sources}

Book

Internet

Health Workers (Doctor, Nurse, Midwives)

$30 \quad 37$

Based on table 1 the age of respondents during the first marriage was 15-18 years as many as 73 respondents $(90.1 \%)$. The number of respondents with last education in junior high school were more than respondents with elementary school and high school, namely 51 respondents (63\%). The highest number of children from respondents is $1-2$ children, 58 respondents (71.6\%). The major income was <Rp. 2,678,028.99 with 71 respondents $(87.7 \%)$. Respondents who received information about the impact of early marriage on pregnancy were 51 people $(63 \%)$ with information sources obtained through books 2.5\%, 12.3\% internet media, 11.1\% counseling, and health workers (Doctors, Nurse, Midwife) $37 \%$. 
Table 2 Women's knowledge about the impact of early marriage on pregnancy $(\mathbf{n}=\mathbf{8 1})$

\begin{tabular}{ccc}
\hline Knowledge Category & Frequency (f) & Percentage (\%) \\
\hline Good & 46 & 57 \\
Moderate & 24 & 29,6 \\
Poor & 11 & 13,5 \\
\hline
\end{tabular}

Based on table 2 above, respondents with good knowledge were 46 people (57\%), sufficient knowledges were 24 people (29.6\%) and poor knowledge were 11 people (13.5\%).

Tabel 3 Women's knowledge about the impact of early marriage on pregnancy $(\mathbf{n}=\mathbf{8 1})$

\begin{tabular}{|c|c|c|c|c|c|}
\hline \multirow[t]{2}{*}{ No } & \multirow[t]{2}{*}{ Question } & \multicolumn{2}{|c|}{ True } & \multicolumn{2}{|c|}{ False } \\
\hline & & $\mathbf{F}$ & $\%$ & $\mathbf{f}$ & $\%$ \\
\hline 1 & $\begin{array}{l}\text { Pregnancy at a young age does not } \\
\text { have any harmful risk of health. }\end{array}$ & 61 & 75,3 & 20 & 24,7 \\
\hline 2 & $\begin{array}{l}\text { Pregnancy at a young age }<18 \text { years } \\
\text { is a factor for a high risk of harmful } \\
\text { pregnancy. }\end{array}$ & 76 & 93,8 & 5 & 6,2 \\
\hline 3 & $\begin{array}{l}\text { A harmful pregnancy is a } \\
\text { pregnancy that would cause the } \\
\text { mother and the fetus to have an } \\
\text { illness or die. }\end{array}$ & 75 & 92,6 & 6 & 7,4 \\
\hline 4 & $\begin{array}{l}\text { The high risk of pregnancy and } \\
\text { childbirth is due to the lack of } \\
\text { physical readiness for women less } \\
\text { than } 20 \text { years old }\end{array}$ & 76 & 93,8 & 5 & 6,2 \\
\hline 5 & $\begin{array}{l}\text { Early marriage is one way to avoid } \\
\text { a high risk of pregnancy }\end{array}$ & 44 & 54,3 & 37 & 45,7 \\
\hline 6 & $\begin{array}{l}\text { Pregnancy at a young age (under } 18 \\
\text { years) has a risk of death to both } \\
\text { the mother and baby }\end{array}$ & 65 & 80,2 & 16 & 19,8 \\
\hline 7 & $\begin{array}{l}\text { Pregnancy at a young age could } \\
\text { lead to stunted fetal growth and } \\
\text { even fetal distress }\end{array}$ & 66 & 81,5 & 14 & 17,3 \\
\hline 8 & $\begin{array}{l}\text { Spontaneous abortion is the } \\
\text { occurrence of abortion that takes } \\
\text { place with an action or } \\
\text { intentionally. }\end{array}$ & 30 & 37 & 51 & 63 \\
\hline 9 & $\begin{array}{l}\text { Stress in pregnant women can cause } \\
\text { miscarriages }\end{array}$ & 80 & 98,8 & 1 & 1,2 \\
\hline 10 & $\begin{array}{l}\text { Pregnancy at the age of fewer than } \\
18 \text { years is not at risk of } \\
\text { miscarriage before the age of the } \\
\text { fetus is } 20 \text { weeks. }\end{array}$ & 42 & 51,9 & 39 & 48,1 \\
\hline
\end{tabular}


Ifna Rosydah : The Impact of Early Marriage on Pregnancy: Young Women's Knowledge

\begin{tabular}{|c|c|c|c|c|c|}
\hline 11 & $\begin{array}{l}\text { Tired, fatigued, dizzy eyes, fast } \\
\text { heartbeat, pale face are symptoms } \\
\text { of anemia in pregnant women }\end{array}$ & 77 & 95,1 & 4 & 4,9 \\
\hline 12 & $\begin{array}{l}\text { Pregnancy at a young age results in } \\
\text { less blood for the mother because } \\
\text { of lack of iron during pregnancy }\end{array}$ & 67 & 82,7 & 14 & 17,3 \\
\hline 13 & $\begin{array}{l}\text { Eat nutritious foods would avoid } \\
\text { pregnant women from pregnancy } \\
\text { disorders }\end{array}$ & 70 & 86,4 & 11 & 13,6 \\
\hline 14 & $\begin{array}{l}\text { The condition of the reproductive } \\
\text { organs (vagina, uterus) that are not } \\
\text { ready for pregnancy can lead to } \\
\text { pregnancy poisoning in the form of } \\
\text { eclampsia and preeclampsia }\end{array}$ & 55 & 67,9 & 26 & 32,1 \\
\hline 15 & $\begin{array}{l}\text { Eclampsia is an acute disorder that } \\
\text { occurs in pregnant women } 20 \\
\text { weeks of gestation / more or } 24 \\
\text { hours after labor which is } \\
\text { characterized by the presence of } \\
\text { convulsions or coma. }\end{array}$ & 64 & 79 & 17 & 21 \\
\hline 16 & $\begin{array}{l}\text { High blood pressure with seizures } \\
\text { is called preeclampsia while high } \\
\text { blood pressure without seizures in } \\
\text { eclampsia }\end{array}$ & 11 & 13,6 & 70 & 86,4 \\
\hline 17 & $\begin{array}{l}\text { Infection during pregnancy does } \\
\text { not result in bodily disability or } \\
\text { organ function in the fetus }\end{array}$ & 38 & 46,9 & 43 & 53,1 \\
\hline
\end{tabular}

18 Pregnant women under the age of

$\begin{array}{llll}55 & 67,9 & 26 & 32,1\end{array}$
18 can cause reproductive disorders or diseases.

19 Pregnancy at a young age has the 35

43,2 $46 \quad 56,8$ potential to cause infertility due to infection with reproductive organs

\begin{tabular}{llllll}
\hline 20 & $\begin{array}{l}\text { Premature birth is a baby born too } \\
\text { early before } 37 \text { weeks of pregnancy }\end{array}$ & 72 & 88,9 & 9 & 11,1 \\
\hline 21 & $\begin{array}{l}\text { Pregnant women younger than 18 } \\
\text { years old are not a risk factor for } \\
\text { premature birth }\end{array}$ & 44 & 54,3 & 37 & 45,7 \\
\hline 22 & $\begin{array}{l}\text { Babies born prematurely affect the } \\
\text { baby's growth }\end{array}$ & 72 & 88,9 & 9 & 11,1 \\
\hline
\end{tabular}


Ifna Rosydah : The Impact of Early Marriage on Pregnancy: Young Women's Knowledge

\begin{tabular}{llllll}
\hline 23 & $\begin{array}{l}\text { Low birth weight (LBW) is a baby } \\
\text { whose weight is more than 2,500 } \\
\text { grams }\end{array}$ & 55 & 67,9 & 26 & 32,1 \\
\hline 24 & $\begin{array}{l}\text { Infants born with abnormal weight } \\
\text { occur due to the lack of nutrients } \\
\text { needed }\end{array}$ & 73 & 90,1 & 8 & 9,9 \\
\end{tabular}

Table 3 above showed women's knowledge about the impact of early pregnancy on the health of women and infants. The impact on women would have a high risk of harmful pregnancy, of which 75 (92.6\%) cause pregnant women to become sick or die, 30 (37\%) miscarriage, $80(98.8 \%)$ chose to stress in pregnant women, 77 (95.1\%) acknowledge signs of anemia. The impact on infants for example $72(88.9 \%)$ answered correctly regarding premature birth, and $72(88.9 \%)$ premature babies affected the growth of the baby.

\section{DISCUSSION}

Based on the results of the study, most women know that early marriage have an impact on pregnancy or pregnancy complications. Someone who has a good concept, acknowledge and understand the effects of early marriage to pregnancy would understand the negative impact of having pregnancy in young ages. This can be influenced by several factors such as information obtained, sociodemographic factors such as age, education, experience, environment, and economy. According to Budiman \& Riyanto (2013) stated that knowledge is influenced by several factors including education, information, social, economic, environmental, experience, and age.

Early married women with moderate knowledge may not fully understand the impact of early marriage on pregnancy. This is in line with Haque's research, Rahman, Mukti, \& Lutfunnahar (2014) $84.61 \%$ of respondents had moderate knowledge about the impact of pregnancy at a young age. The results of this study also found that respondents had less knowledge. Lack of knowledge about sex and delay in pregnancy can cause adolescents to have poor knowledge about the impact or the high risk of pregnancy (WHO, 2011). Early married women never think that their immature physique can cause an infant or mother died during childbirth (Roy, 2016). Efforts to increase knowledge of women who got married early about the impact of early marriage is necessary. According to Mubarak (2007) that counseling is a method carried out to increase knowledge so that it can form a certain attitude. 
Ifna Rosydah : The Impact of Early Marriage on Pregnancy: Young Women's Knowledge

The results of the data showed that majority of the respondents knew that pregnancy at a young age had a high harmful risk for pregnancy and had an impact on death and illness in mothers and infants. As explained by Manuaba (1998) that at the time young women experienced pregnancy, there is a high chance that reproductive health is not optimal and would cause various risks of pregnancy. Thus it is recommended to conduct a health check so that they can prepare themselves for pregnancy in optimal conditions (Manuaba, 1998).

Other data showed that women acknowledge the incidence of spontaneous abortion or miscarriage. In accordance to the study of Husain, Kaeng, and Suparman (2013) the level of respondents' knowledge about spontaneous abortion 55.8\% were good. This study also showed that most respondents know that stress could cause miscarriages. Theory of S. Prawirahardjo (2002, in Rahmani, 2014) stated that in early pregnancy the condition of the mother is still unstable and not mentally ready to accept the pregnancy, as a result, the pregnancy is not properly maintained. This condition causes the mother to get stressed easily and increases the risk of abortion.

The majority of women know that tired, fatigued, dizzy, rapid heartbeat, pale face are symptoms of anemia in young women. Many nutritious foods can prevent pregnant women from anemia. This showed that the mother's knowledge of anemia is good. Teenage girls know that young women still experience growth and experience pregnancy, so there is competition for nutrition with the fetus they contain, so the weight of pregnant women is often difficult to rise and accompanied by anemia (Fadlayana \& Larasaty, 2009).

Other data regarding the impact of early marriage on preeclampsia and eclampsia and most respondents know that the condition of reproductive organs that are not ready for pregnancy can lead to pregnancy poisoning in the form of preeclampsia and eclampsia. In accordance with Savage and Hoho's study (2016), respondents' knowledge of signs and symptoms of preeclampsia or eclampsia is low. This shows that early married adolescents do not understand if the reproductive organs of early married women are not ready to have intercourse or pregnancy, so if they are pregnant they are at risk of developing high blood pressure because their bodies are not strong enough to experience pregnancy so they will experience preeclampsia (BKKBN, 2016).

Respondents acknowledge that getting married less than 18 years old causes reproductive disorders or diseases such as infections. Respondents also knew about the impact of pregnancy at a young age on premature birth and low birth weight babies. According to Manuaba (2008) the condition of pregnant women under the age of 20 is 
still in its growth and is at risk of complications of pregnancy due to biological maternal immaturity, namely the reproductive organs that are not ready so that there is competition for maternal and fetal nutritional needs so that food intake is mostly used to meet the needs of mothers. Therefore, there is a need for health education regarding pregnancy complications, especially LBW, which occurs in pregnant women at a young age.

Based on the results of the analysis, the majority of respondents knew about the impact of early marriage on pregnancy. Budiman and Riyanto (2013) said that education is one of the factors that influence knowledge. Bhandari (2014) stated that there is a relationship between knowledge about the impact of early marriage on pregnancy and the level of education, adolescents with secondary education have good knowledge. In accordance with the characteristics of the respondents of this study, the majority was junior high school education. Nurjanah, Estiwidani, \& Purnamaningrum (2013) mentioned that the implementation of informing with teaching method in the education process is a great way of health education to increase students' knowledge about early marriage and its impact. The results of Nurjanah's study, Estiwidani, \& Purnamaningrum (2013) found that there was an influence of counseling by increasing knowledge about young age marriage and its problems.

In addition, the results of the study found that the majority of women were knowledgeable because they were supported by facilities that made it easier to obtain information. According to research by Ramadani, Nursal, and Ramli (2015), there is a relationship between the role of health workers and the knowledge of adolescents about pregnancy at a young age. The role of health workers as educators plays a role in implementing guidance or counseling, education of clients, families, and the public regarding reproductive health (Kusnanto, 2004). The role of health workers is carried out in the Youth Care Health Service Program (PKPR) which is a health service to adolescents through special treatment tailored to the needs of adolescents. Providing information by health workers includes immunization of brides, and the impact of early marriage on pregnancy (Ramadani, Nursal, \& Ramli, 2015).

\section{CONCLUSION}

It was concluded that women's knowledge of early marriage and pregnancy was good, although there was a small number that is moderate and poor, however the majority of women had limited understanding about preeclampsia. Knowledge of women is less related to preeclampsia and eclampsia, there is a need for health education about preeclampsia and eclampsia for women who had an early marriage. 


\section{REFERENCES}

A.F, O., Shitu, F. A., \& A.R, Y. (2013). The cause and effect of teenage pregnancy: Case of kontagora local government area in Niger State, Northern part of Nigeria. International Open Journal of Educational Research, 1(7), 1-15. http://acascipub.com/Journals.php.

Afifah, K.N., \& Susilawati, D. (2016). Gambaran pengetahuan remaja putri tentang dampak pernikahan dini di Desa Lempong Kecamatan Jenawi Kabupaten Karanganyar. Muswil Ipemi Jateng.

Ali, A. A. A., Ibrahim, I. A., Abdelgbar, S. A., \& Elgessim, M.E. (2014). SocioDemographic factors affecting child marriage in Sudan. Journal of Women's Health Care, 03(04).https://doi.org/10.4172/2167-0420.1000163

Arikunto, S. (2006). Prosedur Penelitian Suatu Pendekatan Praktik. Jakarta : Rineka Cipta.

Astriana, W. (2017). Kejadian anemia pada ibu hamil ditinjau dari paritas dan usia. Jurnal Ilmu Kesehatan 2(2),123-130. http;//ejournal.stikesaisyah.ac.id/index.php/.

Babiker, A. 2016. Knowledge, attitude and practice of early marriage in Eittondoub Area, Aljazeera State. https://www.Researchgate.net/publication/311873830.

Badan Pusat Statistik. (2016). Statistik Kesejahteraan Rakyat. https://bps.go.id/website/pdf_publikasi/Statistik-Kesejahteraan-Rakyat-2016--.pdf. Diakses pada tanggal 11 November 2017.

Bhandari, S. D. (2015). Awareness on consequences of teenage pregnancy adolescent at Ampipal VDC, Gorkha. Journal of Advanced Academic Research, 1(1), 10. https://doi.org/10.3126/jaar.v1i1.13506.

BKKBN. (2016). Risiko pernikahan dini. http://ntb.bkkbn.go.id/_layouts/mobile/dispform.aspx ?List=8c526a76-8b88-44fe8f81-2085df5b7dc7\&View=69dc083c-a8aa-496a-9eb7-b54836a53e40\&ID=714. Diakses pada tanggal 17 Juli 2018.

BKKBN. (2017). Usia Pernikahan Ideal 21-25 Tahun. https://www.bkkbn.go.id/detailpost/bkkbn-usia-pernikahan-ideal-21- 25tahun. Diakses pada tanggal 24 Januari 2018.

Budiman, \& Riyanto, A. (2013). Kapita Selekta Kuesioner. (A. Suslia, Ed.). Jakarta: Salemba Medika.

Chandra-Mouli, V., Camacho, AV, \& Michaud, PA. (2013). Pedoman WHO untuk mencegah kehamilan dini dan hasil reproduksi yang buruk di kalangan remaja di negara berkembang. Jurnal Kesehatan Remaja. https://doi.org/10.1016/j.jadohealth.2013.03.002.

Cunningham, F.G., et al. (1995). Williams Obstetrics. Ed.18. Jakarta: EGC. 
Ifna Rosydah : The Impact of Early Marriage on Pregnancy: Young Women's Knowledge

Ezegwui, H. U., Ikeako, L. C., \& Ogbuefi, F. (2012). Obstetric outcome of teenage pregnancies at a tertiary Hospital in Enugu, Nigeria. Niger J Clin Pract, 15(2), 147-150. https://doi.org/10.4103/1119-3077.97289.

Fadlayana, E., \& Larasaty, S. (2009). Pernikahan usia muda dan permasalahannya. Sari Pediatri, 11(2), 136. https://doi.org/10.14238/sp11.2.2009.136-41.

Febrianti, R. (2015). Hubungan antara usia reproduktif ibu dengan kejadian berat badan lahir rendah (BBLR) di RSUD Goeteng Tarunadibrata Purbalingga. $\quad$ Fakultas Ilmu kesehatan. Universitas Muhammadiyah Purwokerto.

Ganchimeg, T., Ota, E., Morisaki, N., Laopaiboon, M., Lumbiganon, P., Zhang, J. (2014). Pregnancy and childbirth outcomes among adolescent mothers: A World

Health Organization multicountry study. BJOG: An International Journal of Obstetrics and Gynaecology, 121 Suppl 1, 40-48. $\quad$ https://doi.org/10.1111/14710528.12630 .

Ghulmiyah, L., \& Sibai, B. (2012). Maternal mortality from preeclampsia/eclampsia. Seminar in Perinatology. https://doi.org/10.1053/j.semperi.2011.09.011.

Kwesley, E. (2014). Pengetahuan remaja putri mengenai kehamilan di wilayah kerja Puskesmas Klungkung I. Fakultas Kedokteran. Universitas Udayanai, Bali, 1-10.

Lewis, L. N., Hickey, M., Doherty, D. A., \& Skinner, S. R. (2009). How do pregnancy outcomes differ in teenage mothers? A Western Australian study. Med J Aust, 190(10), 537-541. https://doi.org/lew11058_fm [pii]

Nasrullah, M., Zakar, R., Zakar, M. Z., Abbas, S., Safdar, R., Shaukat, M., \& $\quad$ Kramer, A. (2014). Knowledge and attitude towards child marriage practice among women married as children-A qualitative study in urban slums of Lahore, Pakistan. BMC Public Health, 14(1). https://doi.org/10.1186/1471- 2458-14-1148.

Noer, R. I., Ermawati, \& Afdal. (2016). Karakteristik ibu pada penderita abortus dan tidak abortus. Jurnal Kesehatan Andalas, 5(3), 575-583. Retrieved from http://jurnal.fk.unand.ac.id/index.php/jka/article/viewFile/580/468.

Notoatmodjo, S. (2007). Promosi Kesehatan dan Ilmu Perilaku. Jakarta: Rineka Cipta

Nurjanah, R., Estiwidani, D., \& Purnamaningrum, Y. E. (2013). Penyuluhan dan pengetahuan tentang pernikahan usia muda. Jurnal Kesehatan Masyarakat Nasional vol. 8(2). http://journal.fkm.ui.ac.id.

Roy, I. \& Sarker, A.K. (2016). Early marriage impact on female's health and their satisfactory level : A distinctive analytical study in Bangladesh. International Journal of Science and Research volume 5(3). www.ijsr.net.

Sinclair, Constance. (2009). Buku Saku Kebidanan. Jakarta: EGC.

Sinsin, I. (2008). Seri Kesehatan Ibu dan Anak Masa Kehamilan dan Persalinan. Jakarta: PT Elex Media Komputindo. 
Ifna Rosydah : The Impact of Early Marriage on Pregnancy: Young Women's Knowledge

UNICEF. (2018). UNICEF data: Monitoring the situation of children and women. http://data.unicef.org/topic/child-protection/child-marriage/. Diakses pada tanggal 21 April 2018.

WHO. (2011). Early marriages, adolescent and young pregancies. http://apps.who.int/iris/handle/10665/23744

WHO.(2018). Maternal mortality. http://www.who.int/en/news-room/factsheets/detail/maternal-mortality. Diakses pada tanggal 7 Maret 2018.

WHO. (2018). Adolescent pregnancy. http://www.who.int/en/news-room/factsheets/detail/adolescent-pregnancy. Diakses pada tanggal 7 Maret 2018.

Wulandari \& Sarwoprasodjo, Sarwititi. 2014. Pengaruh status ekonomi keluarga terhadap motif menikah dini di Perdesaan. Jurnal Sosiologi Pedesaan. https://www.journal.ipb.ac.id. Diakses pada tanggal 12 November 2017. 